\title{
Benefits of exhaust gas energy for preheating biodiesel fuel to enhance engine emissions and performance
}

Mohamed MOURAD, Elsadek H. NOURELDENN

DOI: 10.30464/jmee.2019.3.2.157

Cite this article as:

Mourad M., Noureldenn E. H. Benefits of exhaust gas energy for preheating biodiesel fuel to enhance engine emissions and performance. Journal of Mechanical and Energy Engineering, Vol. 3(43), No. 2, 2019, pp. $157-168$.

\section{VOLUME 3(43) | No. 2 | JUNE 2019}

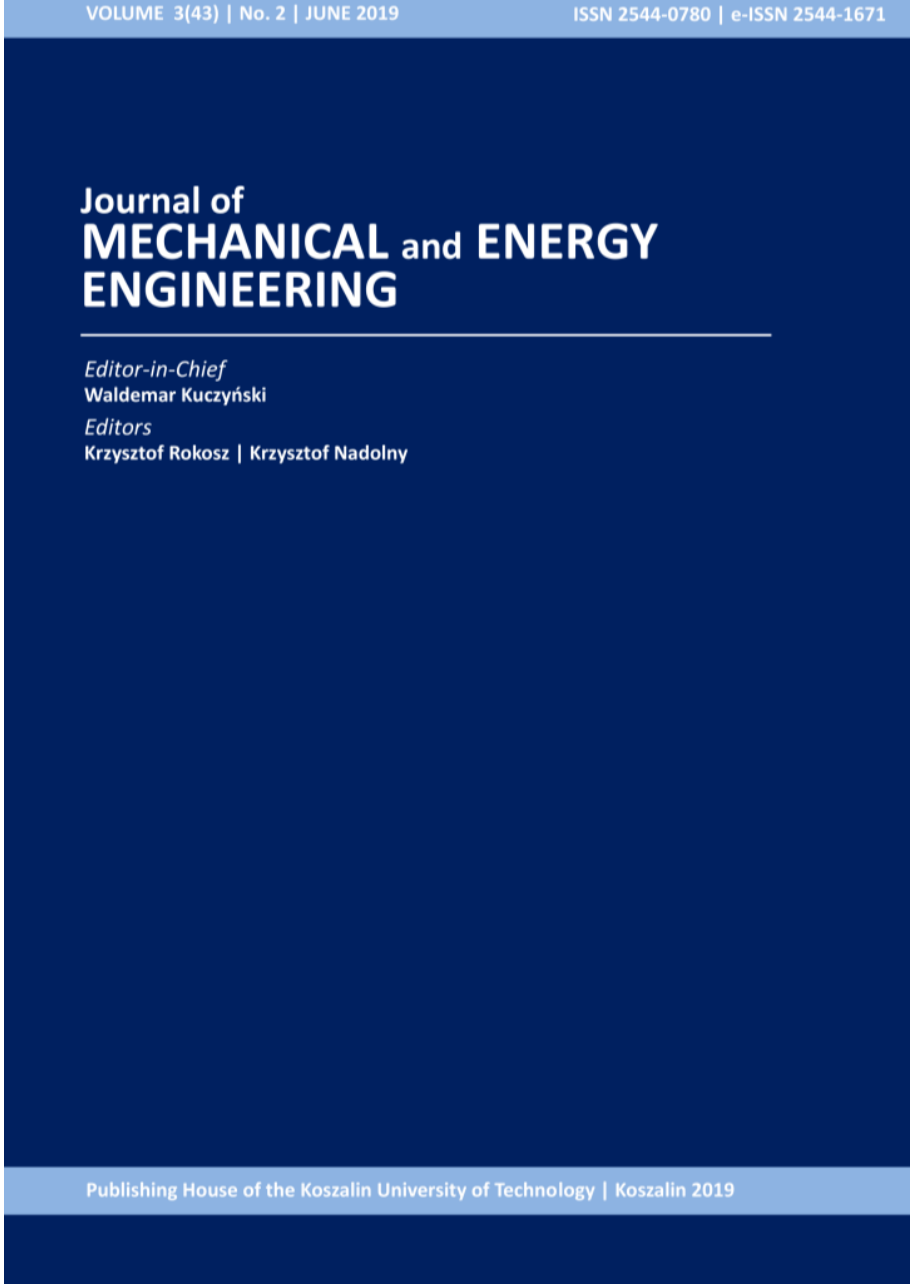

Journal of Mechanical and Energy Engineering

Website: jmee.tu.koszalin.pl

ISSN (Print): 2544-0780

ISSN (Online): 2544-1671

Volume: 3(43)

Number: 2

Year: 2019

Pages: 157-168

Article Info:

Received 17 April 2019

Accepted 8 May 2019

\section{Open Access}

This article is distributed under the terms of the Creative Commons Attribution 4.0 (CC BY 4.0) International License (http://creativecommons.org/licenses/by/4.0/), which permits unrestricted use, distribution, and reproduction in any medium, provided you give appropriate credit to the original author(s) and the source, provide a link to the Creative Commons license, and indicate if changes were made. 


\title{
BENEFITS OF EXHAUST GAS ENERGY FOR PREHEATING BIODIESEL FUEL TO ENHANCE ENGINE EMISSIONS AND PERFORMANCE
}

\author{
Mohamed MOURAD ${ }^{1 *}$, Elsadek H. NOURELDENN ${ }^{1}$ \\ ${ }^{1 *}$ Mechanical Engineering Department, Faculty of Engineering, Minia University, 61111 Minia, Egypt \\ Email: m.mourad@mu.edu.eg, Tel.:00201066351362
}

(Received 17 April 2019, Accepted 8 May 2019)

\begin{abstract}
The need for alternative fuel instead of conventional fossil fuels (diesel or gasoline) has recently increased for several reasons, including the expected shortage of petroleum fossil fuels and the production of pollution by transportation. Consequently, researchers are interested in finding new alternative fuels. At present, the number of studies on biodiesel as a compression ignition engine fuel has increased. Current studies are mainly concerned with studying the use of exhaust gas temperature to preheat biodiesel fuel before it enters the combustion chamber. A heat exchanger is designed to increase the temperature of the biodiesel fuel prior to the combustion process. The performance characteristics of diesel engines and the emission of pollutants resulting from this modification were investigated under different operating conditions, including different engine loads and speeds. The results showed clear improvements in engine performance, including improved output power, specific fuel consumption and pollutant emissions. The engine power and specific fuel consumption improvements as a result of preheating reached up to $1.3 \%$ and $8.27 \%$, respectively. Pollutant emission also decreased obviously, with carbon monoxide and hydrocarbon emission decreases of $12.95 \%$ and $12.85 \%$, respectively. However, the emission of nitrogen oxides increased by $4.39 \%$.
\end{abstract}

Keywords: biodiesel production, preheating, engine emissions, performance

\section{INTRODUCTION}

Various means of transportation have become very important in light of technological and economic progress worldwide. Population growth is steadily increasing with economic activity, which has resulted in increasing transportation needs. With increasing transportation density (especially for various types of diesel vehicles), the amount of pollutants emitted into the atmosphere will increase [1-3]. The pollutants emitted from engine vehicles can cause severe harm to the surrounding environment and humans [4-6]. Industrial and developed countries have legislated laws and regulations to restrict pollution levels from road vehicles. These laws and regulations have placed great pressure on automobile manufacturers to find new ways to reduce emissions from road vehicles [7]. Researchers have also commissioned studies to improve the performance of these engines to reduce pollutant emissions. Several of these studies have focused on the use of alternative fuels to reduce pollutant emissions [8-11].

Biodiesel fuel is an alternative fuel that can reduce the amount of pollution caused by diesel engines [1215]. Recently, automotive researchers have taken an interest in the production of different types of biodiesel from edible and non-edible oil [16-19]. Many methods, including esterification, are used for biodiesel production. Biodiesel is used directly as a fuel for diesel engines or is blended with diesel fuel at different rates to improve engine performance and reduce pollutant emissions [20-23]. Previous studies have focused on the effects of many types of biodiesel fuel on the performance of diesel engines to determine the best conditions for biodiesel use. In addition, many investigations have been conducted to study the effects of different biodiesel blends on engine pollution and performance under different operating conditions [24]. Several of these studies regarding the influences of 
biodiesel on compression ignition (CI) engine performance and emissions are summarized below.

Bari et al. [25] studied the effect of crude soybean oil, a $50 \%$ (by volume) mixture of crude soybean oil and petrodiesel on CI engine performance characteristics and emissions at different engine speeds. The experimental results were compared with sunflower oil and a $50 \%$ blend of sunflower oil with diesel fuel. The study indicated that it was necessary to preheat the oil up to $70-90^{\circ} \mathrm{C}$ to enhance the engine performance and combustion quality. Hazar et al. [26] aimed to study the influences of fuel preheating to $100^{\circ} \mathrm{C}$ on the $\mathrm{CI}$ engine performance and emission characteristics fueled with raw rapeseed oil/diesel blends. The experiments were carried out for two blends (20 and $50 \%$ in volume) in a single cylinder diesel engine. The results indicated that significant improving of engine performance and decreasing of pollutants emission were obtained with preheated (at $100^{\circ} \mathrm{C}$ ) blend 50 and $20 \%$. Pugazhvadivu et al. [27] examined the influence of using mahua oil on the external performance of a single cylinder diesel engine. The output performance and pollutant emissions of the engine were studied to compare the use of diesel fuel and mahua oil. Practical experiments were conducted on the engine using mahua oil at a temperature of $130^{\circ} \mathrm{C}$ to determine the effects of preheating on the engine performance parameters and the pollution emitted from the engine. The results of this investigation showed that the emissions of $\mathrm{CO}$ and hydrocarbon (HC) from the engine significantly decreased while the emission of NOx increased when the mahua oil was preheated. Du et al. [28] used a new method called the electric field strength method to reduce the viscosity of biodiesel fuel. These authors found that the biodiesel viscosity decreased by up to $25.5 \%$, which improved the engine performance and emissions. Tesfa et al. [29] studied the influences of temperature and the biodiesel fraction on the physical properties, such as density and viscosity, of rapeseed, corn oil and waste oil biodiesels-diesel fuel blends and reported new correlations between the density and viscosity of different blends of biodiesel with diesel fuel. Karabektas et al. [30] studied the Performance parameters and exhaust emissions of a diesel engine fuelled with diesel fuel and cottonseed oil methyl ester. Biodiesel was preheated to four different temperatures $30,60,90$ and $120^{\circ} \mathrm{C}$. the experimental investigation focused on external characteristics of diesel engine and pollutants emission.The results indicated that preheating biodiesel up to $90^{\circ} \mathrm{C}$ leads to enhancement on the engine performance and emissions but causes higher NOx emissions. Murillo et al. [31] studied the performance of diesel engines fuelled with the biodiesel-diesel blends B10, B30 and B50 under different operating conditions including different engine speeds and loads. The results of this investigation indicated that the engine output power decreased as the ratio of biodiesel to diesel in the blend increased. In addition, the engine fuel consumption was affected by the operating conditions. Furthermore, the influences of waste cooking oil and low sulphur diesel on diesel engine performance and emissions under different loads were investigated. Kumar et al. [32] evaluated the performance characteristics and pollutant emissions of diesel engines using various rates of cottonseed blended with biodiesel and fuel additives. The experimental result indicated that adding an additive enhanced the output performance of the diesel engine and decreased the $\mathrm{NOx}, \mathrm{CO}$ and $\mathrm{HC}$ emissions. Experimental tests were conducted to study the influences of preheating biodiesel, and the results indicated that engine performance was enhanced and pollutant emissions were decreased. This investigation concluded that engine performance and emissions clearly improved when the fuel inlet temperature was $60^{\circ} \mathrm{C}$.

Previous literature indicates that the use of biodiesel as an alternative fuel is of great interest. Biodiesel can be used in diesel engines to improve engine performance characteristics and emissions. A literature review of the influences of biodiesel fuel on engine performance indicates that few studies have focused on the effects of biodiesel inlet fuel temperature on engine performance and emissions.

Therefore, in this study, the influence of the inlet temperature of biodiesel fuel before it enters the combustion chamber is investigated. Practical experiments are performed on diesel engines at different engine speeds and at different loads to evaluate engine performance and pollutant emissions. The instrumentation systems and measurement equipment were prepared and connected with a diesel engine to measure various performance parameters (output brake power, specific fuel consumption, brake thermal efficiency, exhaust emission). Thermocouples were connected to a digital thermometer and installed in the engine to determine the exhaust and engine temperatures. To control the temperature of the biodiesel fuel at the inlet of the engine, a heat exchanger was designed so that the exhaust heat could be used to preheat the biodiesel before it entered the combustion chamber. The temperature of the biodiesel was controlled by placing a valve in the exhaust path to adjust the amount of exhaust that circulated around the fuel to exchange the heat energy. The temperature of the biodiesel fuel ranged from 30 to $70^{\circ} \mathrm{C}(30-40-$ $50-60-70^{\circ} \mathrm{C}$ ). At each entry, the biodiesel temperature was considered when evaluating the engine performance and pollutant emissions at different engine speeds and loads. These experimental tests are listed in prepared tables, and the experimental results were processed to study the effects of the inlet 
temperature of biodiesel fuel on engine performance. The experimental results show clear differences in engine performance regarding output power, specific fuel consumption and pollutant emissions due to differences in the biodiesel inlet temperature. The engine power and fuel consumption were enhanced by $1.3 \%$ and $8.27 \%$, respectively, as a result of preheating. The $\mathrm{CO}$ and $\mathrm{HC}$ emissions decreased by $12.95 \%$ and $12.85 \%$, respectively, and the NOx emissions increased by $4.39 \%$ at an engine load of $75 \%$. From these results, it can be concluded that preheating biodiesel fuel has a significant influence on engine performance characteristics and emissions.

\section{MATERIALS AND METHODS}

This section reviews the method of biodiesel production and describes the experimental setup. The method used for biodiesel production from sunflower oil in the laboratory is presented in detail, and the physical and chemical properties of the biodiesel fuel are presented. The description of the experimental setup describes the experimented diesel engine and the instrumentation systems used in the laboratory to measure all engine performance and emission variables under different operating conditions.

\subsection{Biodiesel production}

The chemical and physical properties of biodiesel fuel depend on the original oil source, such as virgin edible, non-edible or used cooking oils. The production of biodiesel fuel from sunflower oil was executed in the laboratory according to the esterification method [33-35].
The raw materials used in the reaction are sunflower oil, methanol and catalyst $\mathrm{KOH}$ (potassium hydroxide). Chemical reactions must be done in an atmosphere free of moisture. Figure 1 shows a schematic diagram of biodiesel production procedures. The following steps describe the biodiesel production method used in the laboratory [36-39]:

- first, mix $200 \mathrm{ml}$ of methanol with $7 \mathrm{~g}$ of $\mathrm{KOH}$ in a flask,

- heat the mixture to $50^{\circ} \mathrm{C}$ and stir it well to guarantee that the methanol and $\mathrm{KOH}$ solution is thoroughly mixed,

- prepare 11 of pure sunflower oil and heat the oil to $60^{\circ} \mathrm{C}$,

- mix the catalyst and methanol with the oil in a bowl. Next, place the bowl in a water bath at $55^{\circ} \mathrm{C}$ and stir it well for at least one hour,

- then, place the final solution in a tightly closed glass container for the separation and allow it to stand for 24 hours,

- after 24 hours, the upper layer is biodiesel fuel and the lower layer is glycerol that must be separated from the biodiesel,

- next, wash the biodiesel with cold and hot water several times to remove the glycerol,

- determine the chemical and physical properties of the biodiesel fuel, such as the fuel density and viscosity,

- repeat the experiment several times to obtain an amount of biodiesel that is sufficient for laboratory experiments.

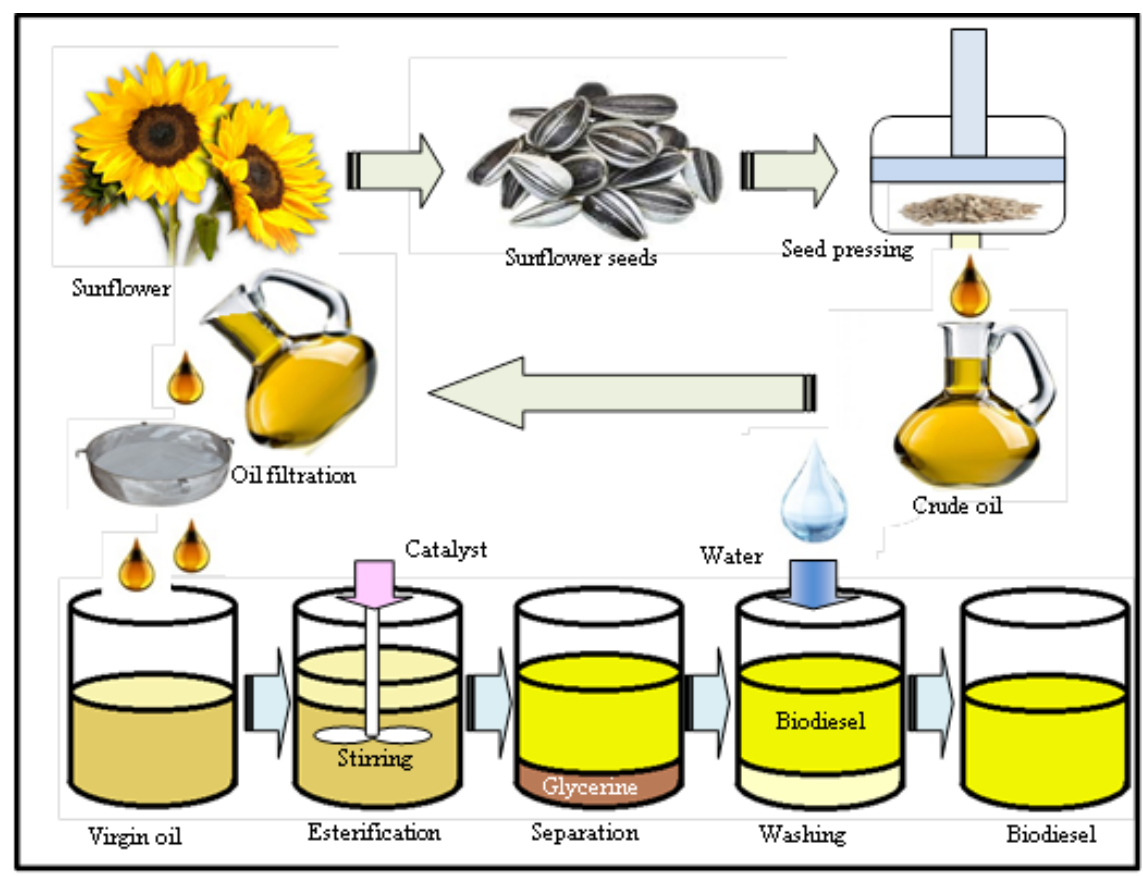

Fig. 1. Schematic diagram of biodiesel production procedures 
The conversion of sun flower oil into biodiesel was done in accordance with the steps described above. In order to ensure to carry-out all experimental work on the engine, a sufficient amount of biodiesel fuel has been produced. Table 1 illustrates the significant properties of biodiesel fuel and conventional diesel.

Tab. 1. Biodiesel and conventional diesel properties

\begin{tabular}{lcc}
\hline Property & Biodiesel & Diesel \\
\hline Density g/cm & 0.885 & 0.842 \\
\hline $\begin{array}{l}\text { Kinematic Viscosity cSt @ } \\
40^{\circ} \mathrm{C}\end{array}$ & 4.6 & 3.34 \\
\hline Cetane number & 47 & 55 \\
\hline Flash point ${ }^{\circ} \mathrm{C}$ & 92 & 70 \\
\hline Calorific value, $\mathrm{MJ} / \mathrm{kg}$ & 43.1 & 45.4 \\
\hline
\end{tabular}

\subsection{Experimental setup}

A heat exchanger is designed to take advantage of the waste energy that the diesel engine rejects to the surrounding through the exhaust system. Hot gases from the tail pipe are used to preheat the fuel in the heat exchanger box, using a heat exchanger attached to a branch of the exhaust pipe. A heat exchanger was designed to utilize the rejected exhaust enthalpy to preheat the biodiesel fuel in range $30^{\circ} \mathrm{C}$ up to $70^{\circ} \mathrm{C}$ before it entered the diesel engine combustion chamber. It is a fuel tank in which a pipe branching from the main exhaust pipe is passed through in a spiral, as shown in Fig. 2. The biodiesel temperature is controlled by a valve installed on the exhaust pipe to control the exhaust flow rate. The preheated biodiesel fuel is drained to another tank placed on a sensitive scale to determine the mass of fuel consumed with time. The fuel tank delivers fuel to the fuel pump and engine after the temperature of the fuel is adjusted. To complete the practical experiments, multiple devices were used to measure engine performance and properties (pollutant emissions, fuel consumption, electric power, engine speed, air flow rate, exhaust and engine temperatures).

A $10.4 \mathrm{~kW}$ off-road diesel engine equipped with an electric generator was used to accomplish the experimental work. The electric generator equipped with a CI engine converts the mechanical power produced from the engine into electrical power. To consume the produced electric power, controllable thermal resistors are connected to increase the thermal load gradually. In order to ensure the accuracy of the thermal load measurement to determine the output torque of the CI engine during the practical experiments. The current and voltage are measured on the cable connected to the thermal resistors by clamp instrument. This technique enables to determine the value of electrical energy consumed by thermal resistors accurately. Electric power consumption is calculated by multiplication the voltage, the current and power factor. From previous calculations, engine power can be calculated after considering the efficiency of the electric generator at all different operating conditions. Practical experiments are performed when the inlet temperature of the biodiesel is changed at different loads and engine speeds. Table 2 indicates the technical specification of the diesel engine used to conduct the experimental work.

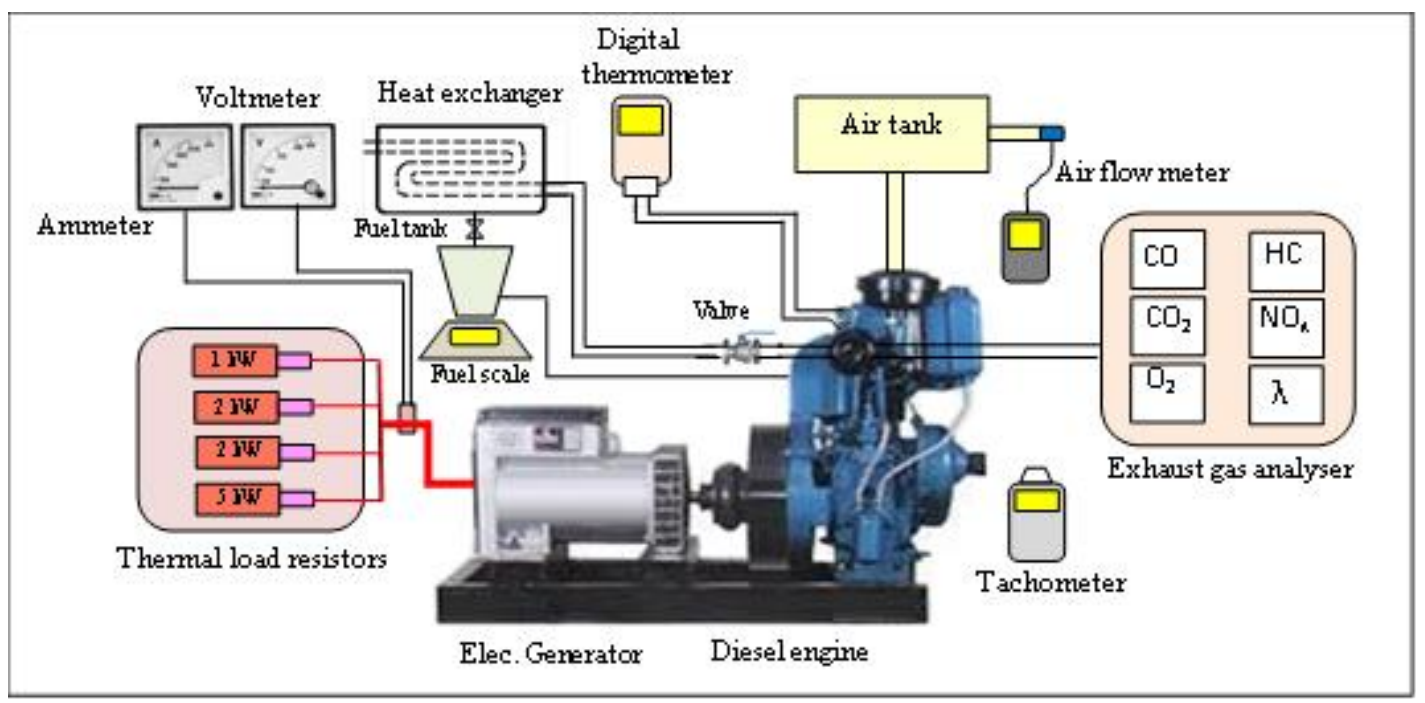

Fig. 2. Schematic diagram of the diesel engine and instrumentation system 
Tab. 2. Technical specification of the CI engine

\begin{tabular}{ll}
\hline Engine parameter & Value \\
\hline Engine model & P.C.U. \\
\hline Engine type & Diesel \\
\hline Displacement, $\mathrm{cm}^{3}$ & 1190 \\
\hline Number of cylinder & 1 \\
\hline Compression ratio & 15 \\
\hline Bore/Stroke, mm & $114 / 116$ \\
\hline Cooling type & Air \\
\hline Max power kW@ rpm & $10.4 @ 1500$ \\
\hline
\end{tabular}

Table 3 provides the different accuracies and uncertainties of the measured properties. Table 4 shows the test conditions of the experimental work.

Tab. 3. Accuracies and uncertainties of the measured properties

\begin{tabular}{lll}
\hline Property & Accuracy & Uncertainty \\
\hline Load & $\pm 0.2 \mathrm{~N}$ & $\pm 0.2 \%$ \\
\hline Power & - & $\pm 0.2 \%$ \\
\hline Fuel consumption & $\pm 2.0 \mathrm{~g} / \mathrm{h}$ & $\pm 1.5 \%$ \\
\hline Air flow rate & $\pm 1.0 \mathrm{~cm}^{3} / \mathrm{h}$ & $\pm 0.2 \%$ \\
\hline $\begin{array}{l}\text { Brake thermal } \\
\text { efficiency }\end{array}$ & - & $\pm 2.5 \%$ \\
\hline Engine speed & $\pm 15 \mathrm{rpm}$ & $\pm 0.5 \%$ \\
\hline Temperatures & $\pm 1{ }^{\circ} \mathrm{C}$ & $\pm 0.1 \%$ \\
\hline Carbon monoxide & $\pm 0.15 \mathrm{~g} / \mathrm{kWh}$ & $\pm 0.2 \%$ \\
\hline Hydrocarbon & $\pm 0.10 \mathrm{~g} / \mathrm{kWh}$ & $\pm 0.2 \%$ \\
\hline Carbon dioxide & $\pm 0.50 \mathrm{~g} / \mathrm{kWh}$ & $\pm 1.0 \%$ \\
\hline Nitrogen oxides & $\pm 0.10 \mathrm{~g} / \mathrm{kWh}$ & $\pm 0.2 \%$ \\
\hline
\end{tabular}

Tab.4. Experimental conditions

\begin{tabular}{ll}
\hline Parameter & Value \\
\hline Engine speed, rpm & 1500 \\
\hline Ambient temperature, ${ }^{\circ} \mathrm{C}$ & 30 \\
\hline Relative humidity, $\%$ & 50 to 55 \\
\hline Air density, $\mathrm{kg} / \mathrm{m}^{3}$ & 1.18 \\
\hline Lubricating oil temperature, ${ }^{\circ} \mathrm{C}$ & 77 to 84 \\
\hline
\end{tabular}

\section{RESULTS AND DISCUSSION}

This section deals in detail with experimental results to illustrate the effect of fuel preheating on engine performance and emission. The discussion of the results is divided into two main parts. The first part interests in the results of the engine performance such as output power, SFC and brake thermal efficiency at different loads and constant speed. The second part explains the engine emission of pollutants such as carbon monoxide, carbon monoxide, hydrocarbons and nitrogen oxides.

\subsection{Engine performance results}

Practical tests were performed on a small diesel engine to study the effects of inlet fuel temperature on engine performance. The inlet fuel temperature was only changed for biodiesel fuel; the inlet temperature of the diesel remained at the ambient temperature of $30^{\circ} \mathrm{C}$. Biodiesel viscosity can be considered as the main reason why the effects of biodiesel preheating should be studied. Therefore, experiments were conducted to assess the performance of the engine at different biodiesel inlet temperatures (30, 40, 50, 60 and $70^{\circ} \mathrm{C}$ ). The results are presented for engine performance and pollutant emissions at different loads of up to $75 \%$ of the full load. Figure 3 shows the relationship between diesel engine powers at different loads while the biodiesel inlet temperature was changed. From Fig. 3, it can be shown that the engine power during the use of traditional diesel was higher than that of biodiesel at $30^{\circ} \mathrm{C}$. This difference occurred for several reasons, among which the most important reason is that the heating value of the biodiesel is lower than that of ordinary diesel, which decreases the power of the engine when biodiesel is used.

Figure 3 shows that the higher biodiesel fuel temperatures at the inlet into the engine correspond with smaller differences in the engine output power between the different types of fuel. This phenomenon indicates that a high biodiesel temperature at the inlet increases the degree of fuel evaporation inside the combustion chamber and thus improves the combustion behaviour of the fuel, which reduces the difference in the output power for both fuels. Increasing the biodiesel temperature at the inlet improves fuel atomization during the injection process, which increases the uniformity within the combustion chamber, improves the engine power, and reduces the difference between the biodiesel and diesel.

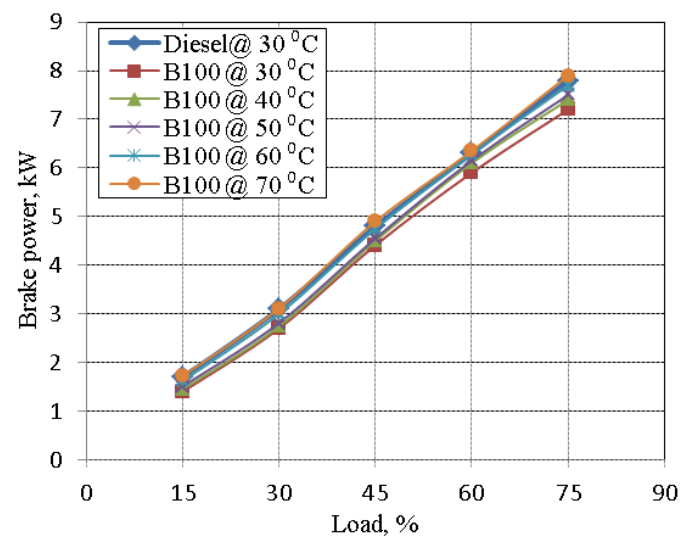

Fig. 3. Output engine power at different loads 


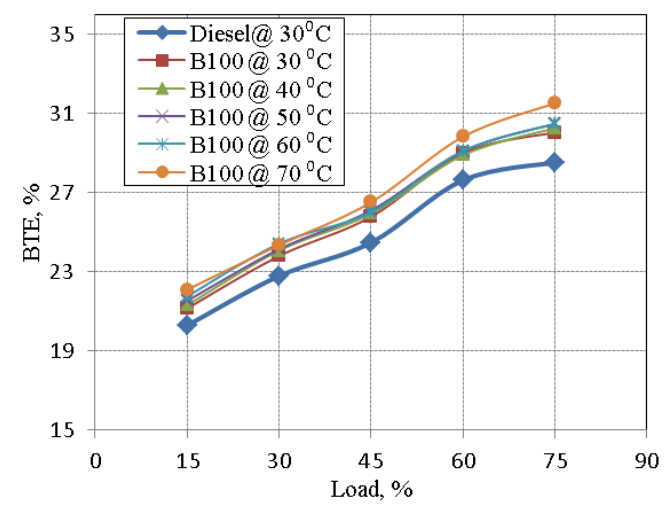

Fig. 4. Brake thermal efficiency of the engine at different loads

Figure 4 shows the brake thermal efficiency (BTE) of the diesel engine at $1500 \mathrm{rpm}$ and at different loads. A comparison of the BTE of diesel fuel at the ambient temperature of $30^{\circ} \mathrm{C}$ and the biodiesel fuel at different inlet temperatures is illustrated in Fig. 4. It can be observed from Fig. 4 that the BTE is clearly improved by increasing the temperature of the biodiesel at the inlet. This improved BTE can be explained by the greater temperature of the biodiesel at the inlet of the combustion chamber because the temperature alters the biodiesel density and viscosity. The higher temperature leads to better evaporation of the biodiesel fuel and thus enhances the mixing of the evaporated fuel with the air and improves the efficiency of combustion (resulting in more complete fuel combustion) [40-43]. Improved combustion within the combustion chamber means that less fuel is consumed and that the output power is higher. Since BTE is directly proportional to engine power and vice versa for fuel consumption, any change in these parameters will affect the BTE. From Fig. 4, the difference in BTE of two fuels is relatively low at low and partial loads. As the engine load increases, the percentage difference of the BTE increases and reaches up to $3 \%$ (the inlet temperature of the biodiesel fuel at $70^{\circ} \mathrm{C}$ and the inlet temperature of the diesel fuel at ambient temperature)

Figure 5 shows the brake specific consumption (BSFC) of biodiesel and diesel fuel at different loads that were used to study the effects of preheating engine fuel on consumption. First, preheating biodiesel fuel could enhance the physical properties of the biodiesel, such as the density and viscosity of the fuel [44]. Also, preheating the fuel can improve the combustion efficiency by reducing the ignition delay period and prolonging the propagation of the flame front. The BSFCs for the two fuels decreased with increasing engine load for the different biodiesel fuel inlet temperatures.

Figure 5 shows that the biodiesel BSFC is higher than the diesel BSFC at the low inlet temperatures. This difference results from the heating value of the fuel. It is known that the heating value of diesel fuel is higher than that of biodiesel fuel; thus, the BSFC of the biofuel increases relative to the BSFC of diesel under the same operating conditions. As the temperature of the biodiesel fuel increases before the injection process, the BSFC somewhat decreases, and when the preheating temperature increases to $70^{\circ} \mathrm{C}$, the BSFC significantly decreases. This result can be explained by the decreased density and viscosity of the biodiesel with increasing temperature, which helps to atomize the fuel particulates and enhance their mixing with air, leading to complete combustion and decreasing the BSFC.

Figure 6 shows the exhaust gas temperatures (EGTs) for both diesel and biodiesel fuel at different fuel inlet temperatures during variant loads. The results show that the exhaust temperature increases when the engine load increases because the engine consumes more fuel and thus produces higher energy at high loads. Therefore, the exhaust temperature increases under these conditions. Figure 6 also shows that the exhaust temperature increases as the temperature of the biodiesel before it enters the engine increases. This result can be explained by the improved combustion within the engine; therefore, the exhaust temperature increases as the temperature of the biodiesel fuel at the inlet increases. The maximum exhaust temperature occurs when the biodiesel temperature at the inlet temperature reaches $70^{\circ} \mathrm{C}$.

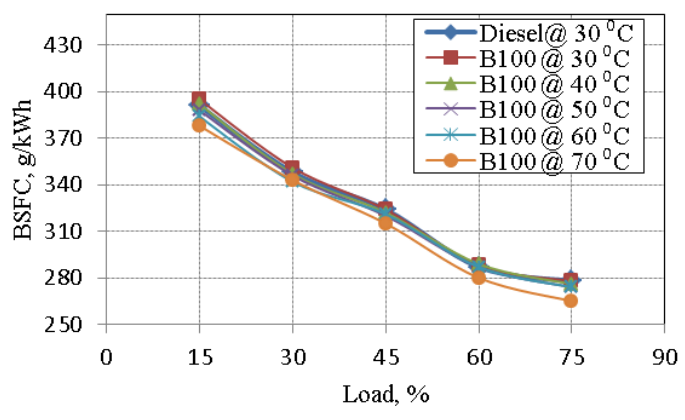

Fig. 5. Brake specific fuel consumption of the engine at different loads

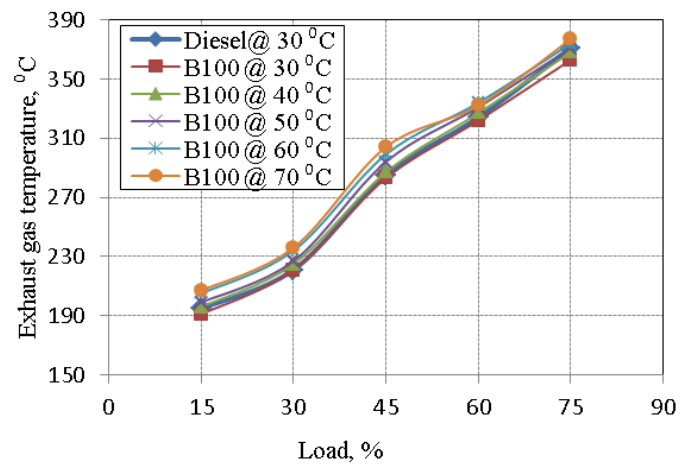

Fig. 6. Exhaust gas temperature of the engine at different load 
Figure 7 shows a comparison of the changes in engine performance characteristics such as PB, BSFC, BTE and EGT when different biodiesel inlet temperatures are used at an engine load of $75 \%$ for biodiesel fuel and diesel (as a baseline).

From Fig. 7, the output power of the engine fuelled by biodiesel is clearly lower than that of the engine fuelled by diesel for the different inlet temperatures. The power of the engine fuelled with conventional diesel was $7.8 \%$ higher than the power of the engine fuelled with biodiesel at the ambient inlet temperature. Also, the higher biodiesel inlet temperatures corresponded with smaller differences in the output power produced from the engine. This smaller difference was observed because the fuels where able to mix better with air and combust within the engine when the inlet temperature was high, which increased the engine power.

Figure 7 also shows the difference between the BSFC of the engine for biodiesel and diesel when different inlet temperatures were used. This figure indicates that the BSFC is lower in the case of biodiesel than in the case of diesel. The difference of the BSFC increases as the biodiesel inlet temperatures increases due to the improvement of combustion within the engine cylinders, which thereby reduces the BSFC. It is also evident from Fig. 7 that the difference of the BSFC is greater than $8 \%$ for the biodiesel fuel when the inlet temperature is $70^{\circ} \mathrm{C}$ because the physical properties of the biodiesel, such as the density and viscosity, are improved; thus, the combustion is almost complete [32-33]. Because the BTE depends on the BSFC of the engine, the BSFC behaviour of the biodiesel fuel at different inlet temperatures directly affects the BTE of the engine. Noticeably, the BSFC of the biodiesel is lower in all cases, and the rate of decline increases as the biodiesel temperature at the inlet into the engine increases to $70^{\circ} \mathrm{C}$. Since BTE is inversely proportional to BSFC and the calorific value of the fuel, each element has an effect on efficiency. It is obvious that the BTE of the biodiesel engine is higher than the BTE of the diesel engine because the BSFC decreases when the biodiesel fuel is preheated.

A comparison of the EGTs of biodiesel and diesel fuels indicates that the EGT increases when the engine operates with preheated biodiesel fuel, especially when the inlet temperature is high. This effect can be observed when the inlet temperature of the biodiesel is high, which causes good combustion and thus increases the temperature of the exhaust gases.

\subsection{Engine emission results}

Carbon dioxide $\left(\mathrm{CO}_{2}\right)$ emissions are considered to be an indicator of the combustion status and BSFC of an engine. There is a direct relationship between the BSFC and $\mathrm{CO}_{2}$ emissions of an engine [45]. It is clear from the figures presented within this manuscript that $\mathrm{CO}_{2}$ emissions increase when the BSFC increases, and vice versa. In Fig. 8 , it can be observed that $\mathrm{CO}_{2}$ emissions were lower when biodiesel was used as the engine fuel, especially when the inlet temperature of the biodiesel was increased.

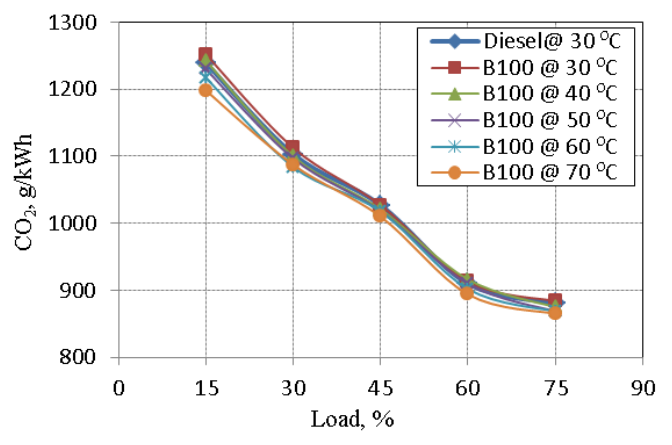

Fig. 7. $\mathrm{CO}_{2}$ emission of engine at different loads

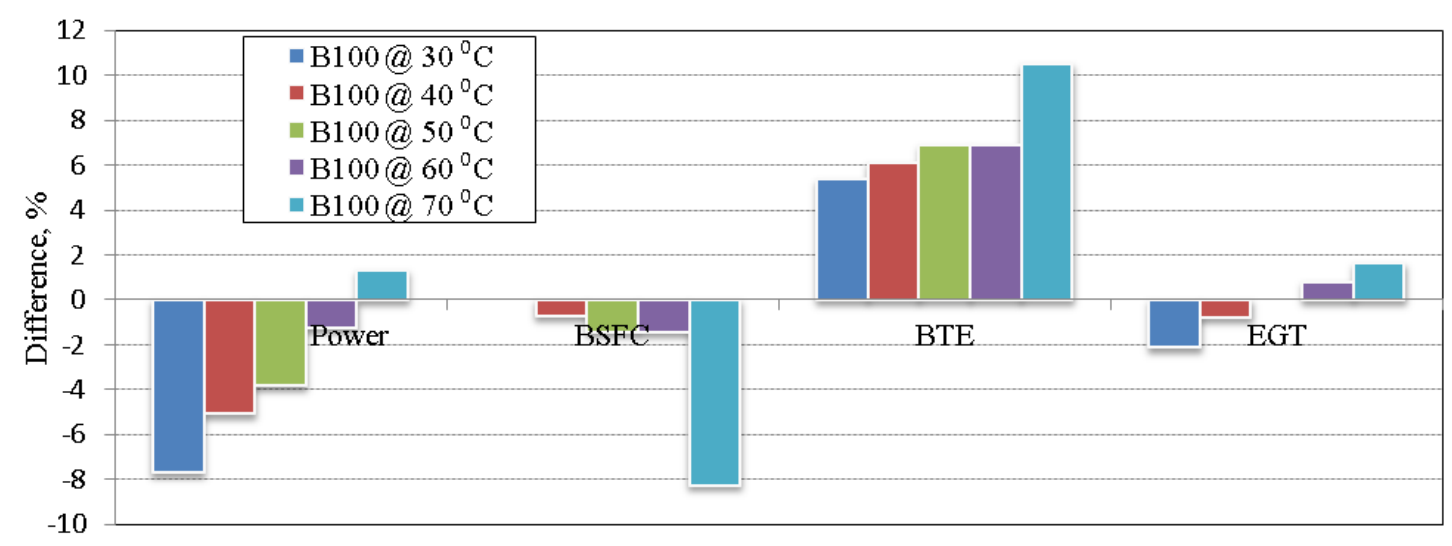

Fig. 8. Differences in engine performance characteristics ( $\mathrm{P}_{\mathrm{B}}, \mathrm{BSFC}, \mathrm{BTE}$ and EGT, in \%) for the different inlet biodiesel and conventional diesel inlet temperatures (baseline: diesel fuel) at an engine load of $75 \%$. 
Figure 9 illustrates the effects of engine loading on carbon monoxide (CO) emissions from diesel and biodiesel fuel combustion when different fuel inlet temperatures are used. The $\mathrm{CO}$ emissions decreased with increasing engine load due to the presence of eddy current flow inside the combustion chamber, which led to good mixing, improved combustion, and reduced $\mathrm{CO}$ emissions. This effect occurred because the oxygen content of the sunflower biodiesel enhanced the ignition properties and split the heavier particulates of the fatty acid present in the biodiesel into smaller particulates that could then be converted into volatile gases and lead to earlier ignition [46].

Figure 9 shows that less $\mathrm{CO}$ was emitted when using biodiesel than when using diesel due to the content of oxygen in the biodiesel fuel, which helped to increase the combustion efficiency and reduce $\mathrm{CO}$ emissions. Figure 9 also shows that the higher biodiesel inlet temperatures resulted in lower $\mathrm{CO}$ emissions due to the improvement of combustion inside the engine cylinders [47].

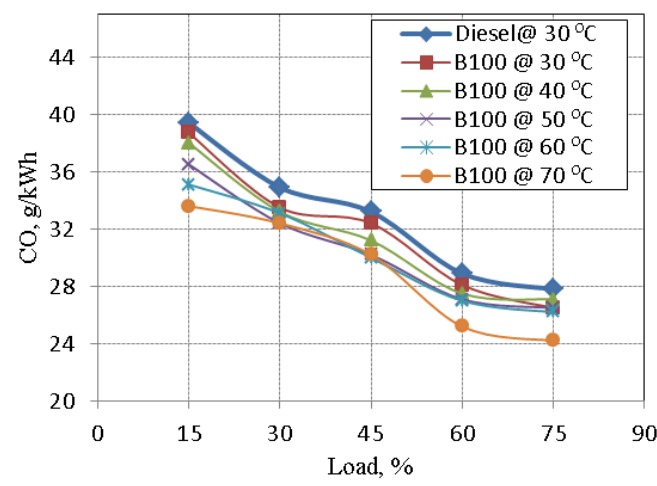

Fig. 9. $\mathrm{CO}$ emissions from the engine at different loads

The incomplete components of diesel and biofuel combustion are $\mathrm{HC}$ and $\mathrm{CO}$ pollutants. These components are directly affected by the mixing and combustion gradients inside the engine combustion chamber. Therefore, when using biodiesel, ignition is delayed, allowing for further fuel evaporation that reduces the emissions of $\mathrm{HC}$. The inlet temperature of biodiesel has a great impact on the atomization and evaporation of fuel inside the combustion chamber, which improves combustion and generally reduces $\mathrm{HC}$ emissions, as shown in Fig. 10.

Two significant parameters affect the emission of NOx. The first parameter is the temperature of the combustion gases within the combustion chamber, and the second parameter is the exposure time for high heat. Both of these factors lead to the generation of NOx [38]. Biodiesels have greater oxygen contents than other fuels, which improves their combustion behaviour and hence increases the peak combustion gas temperature and results in an increase in NOx emissions [48]. NOx emissions are emitted from exhaust gas systems at higher concentrations due to the rapid auto-ignition produced by the high temperature of combustion gases. Therefore, by increasing the inlet temperature of the biodiesel, the exiting NOx concentration will increase at different engine loads, as shown in Fig. 11.

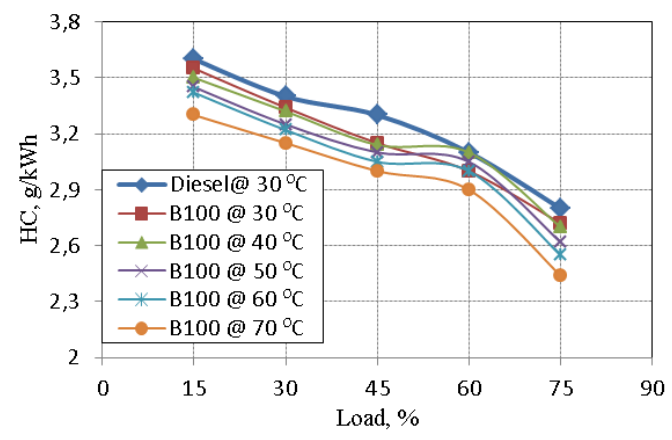

Fig. 10. HC emissions from the engine at different loads

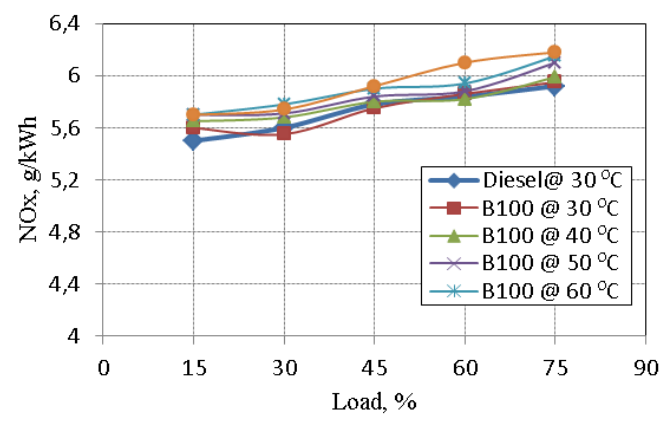

Fig. 11. $\mathrm{NO}_{\mathrm{x}}$ emissions from the engine at different loads

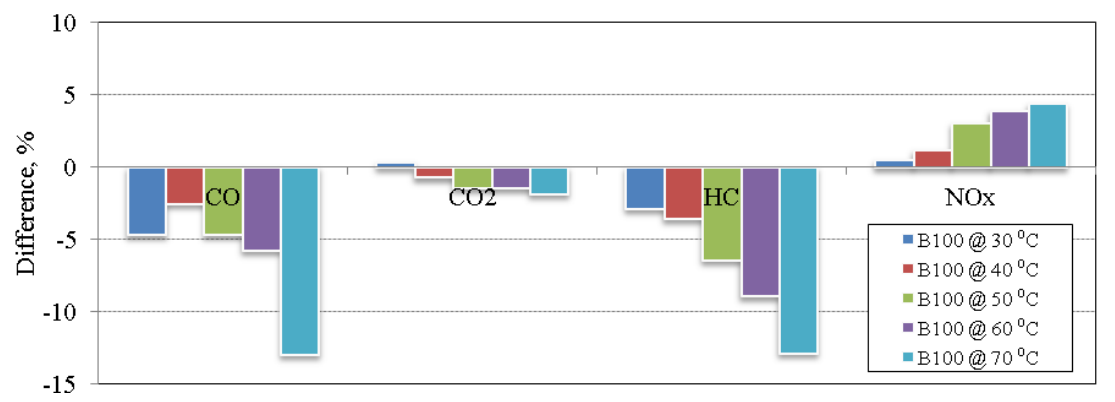

Fig. 12. Difference percentages of the engine emission pollutants $\left(\mathrm{CO}_{2}, \mathrm{CO}, \mathrm{HC}\right.$ and $\left.\mathrm{NO}_{\mathrm{x}}\right)$ at different biodiesel and conventional diesel inlet temperatures (baseline: diesel fuel) at an engine load of $75 \%$. 
Figure 12 shows a comparison of all the pollutants emitted from the engine, such as $\mathrm{CO}_{2}, \mathrm{CO}, \mathrm{HC}$ and NOx at an engine load of $75 \%$ and for different biodiesel inlet temperatures. It is clear from the figure that the difference percentages of $\mathrm{CO}$ and $\mathrm{HC}$ emissions are very low in the case of biodiesel with the difference percentages reaching up to $12 \%$ for a high inlet temperature. A slight difference in $\mathrm{CO}_{2}$ emissions was observed for the benefit of the biodiesel that reached up to $2 \%$. Figure 12 clearly shows that the NOx emissions in the case of biodiesel use are higher than those in the other case (conventional diesel) at all of the biodiesel preheating levels . Generally, Fig. 12 shows that the NOx emissions from the biodiesel fuel are higher than those from diesel.

\section{CONCLUSIONS}

An experimental study was carried out on a diesel engine fuelled with sunflower oil biodiesel to evaluate the engine's performance characteristics and pollutant emissions. The conclusions drawn from the experimental results of biodiesel and conventional diesel fuel studies are summarized below.

1. A heat exchanger was designed to utilize with exhaust enthalpy energy to preheat the biodiesel fuel before entering the combustion chamber of the engine. The biodiesel was heated by a heat exchanger to achieve temperatures of $30^{\circ} \mathrm{C}$ to $70^{\circ} \mathrm{C}$. The inlet temperature of the biodiesel was controlled to ensure that the fuel temperature remained constant during the experiments.

2. The engine was studied at an engine speed of 1500 rpm and under changeable loads. The performance characteristics of the engine, such as the engine output power, BTE and BSFC, were determined. The emissions of different pollutants such as $\mathrm{CO}_{2}$ $\mathrm{CO}_{2}, \mathrm{HC}$ and $\mathrm{NO}_{\mathrm{x}}$ were measured for different operating conditions.

3. The engine power as lower when preheated biodiesel with inlet temperatures of 30, 40, 50 and $60^{\circ} \mathrm{C}$ were used. The engine power improved by $1.3 \%$ at $70^{\circ} \mathrm{C}$ and for a load of $75 \%$. The BTE was greater when the engine was powered by biodiesel rather than diesel, especially when the biodiesel temperature at the inlet was high, which resulted in an improvement of $10.51 \%$.

4. The BSFC was significantly reduced when the engine was fuelled by $70^{\circ} \mathrm{C}$ preheated biodiesel rather than by diesel fuel, with a decrease of 8.27 $\%$. $\mathrm{CO}_{2}$ emissions were also reduced when biodiesel was used for all inlet temperatures, and the maximum reduction in $\mathrm{CO}_{2}$ emissions occurred at an inlet temperature of $70^{\circ} \mathrm{C}$ and a load of $75 \%$.

5. The emissions of $\mathrm{CO}$ and $\mathrm{HC}$ from the $\mathrm{CI}$ engine demonstrate the significant effect of using preheated biodiesel fuel. The rates of $\mathrm{CO}$ and $\mathrm{HC}$ emissions were reduced by $12.95 \%$ and $12.85 \%$, respectively, for different inlet temperatures when biodiesel was used.

6. One obvious drawback of using biodiesel in combustion engines is the resulting $\mathrm{NO}_{\mathrm{x}}$ emissions. When using biodiesel, the engine emits larger amounts of $\mathrm{NO}_{\mathrm{x}}$ when using biodiesel at all inlet temperatures and the difference reaches up to $4.39 \%$ at $70^{\circ} \mathrm{C}$ and load $75 \%$.

\section{Nomenclature}

$$
\begin{aligned}
& \text { Acronyms } \\
& \text { BSFC - Brake specific fuel consumption } \\
& \text { B0 - Pure diesel fuel } \\
& \text { B10 - Biodiesel 10\% } \\
& \text { B10 - Pure biodiesel } \\
& \text { B15 - Biodiesel 15\% } \\
& \text { B20 - Biodiesel 20\% } \\
& \text { B50 - Biodiesel 50\% } \\
& \text { BTE - Brake thermal efficiency } \\
& \text { CI - Compression ignition } \\
& \mathrm{CO} \text { - Carbon monoxide } \\
& \mathrm{CO}_{2} \text { - Carbon dioxide } \\
& \text { cSt - Centistoke units } \\
& \text { EGT - Exhaust gas temperature } \\
& \text { HC - Hydrocarbon } \\
& \text { IC - Internal combustion } \\
& \mathrm{KOH} \text { - Potassium hydroxide } \\
& \mathrm{NO}_{\mathrm{x}} \text { - Nitrogen oxides }
\end{aligned}
$$

\section{References}

1. An H, Yang WM, Maghbouli A, Li J, Chou SK, Chua KJ. Performance, combustion and emission characteristics of biodiesel derived from waste cooking oils. Appl Energy 2013; 112:493-9.

2. Cheikh K, Sary A, Khaled L, Abdelkrim L, Mohand T. Experimental assessment of performance and emissions maps for biodiesel fueled compression ignition engine. Applied Energy 2016; 161: 320-329.

3. Farobie O, Matsumura Y. State of the art of biodiesel production under super critical conditions. Progress in Energy and Combustion Science 2017; 63: 173-203.

4. Ong H, Masjuki H, Mahlia T, Silitonga A, Chong W, Yusaf T. Engine performance and emissions using Jatropha curcas, Ceiba pentandra and Calophyllum inophyllum biodiesel in a CI diesel engine. Energy 2014; 69:27-45.

5. Fattah IMR, Masjuki HH, Kalam MA, Mofijur M, Abedin MJ. Effect of antioxidant on the performance and emission characteristics of a diesel engine fueled with palm biodiesel blends. Energy Conversion Management 2014;79:65-72.

6. Knothe G, Razon L. Biodiesel fuels. Progress in Energy and Combustion Science 2017; 58: 36-59.

7. Fadhil AB. Evaluation of apricot (Prunus armeniaca L.) seed kernel as a potential feedstock for the production of liquid bio-fuels and activated carbons. Energy Convers Manage 2017; 133:307-17.

8. Yang W, An H, Li J, Duan L. Impact of methane addition on the performance of biodiesel fueled diesel engine. Applied Energy 2015;160: 784-792

9. Tripathi S, Subramanian K. Experimental investigation of utilization of Soya soap stock based acid oil biodiesel 
in an automotive compression ignition engine. Applied Energy 2017; 198: 332-346.

10. Hyun KS, Chang SL. A review on atomization and exhaust emissions of a biodiesel-fueled compression ignition engine. Renewable Sustainable Energy Review 2016; 58:1601-1620.

11. Liu H, Wang Z, Wang JX. Performance, Combustion and Emission Characteristics of Polyoxymethylene Dimethyl Ethers (PODE 3-4)/Wide Distillation Fuel (WDF) Blends in Premixed Low Temperature Combustion (LTC). SAE International Journal of Fuels and Lubricants 2015; 8: 298-306.

12. An H, Yang WM, Maghbouli A, Chou SK, Chua KJ. Detailed physical properties prediction of pure methyl esters for biodiesel combustion modeling. Applied Energy 2013; 102:47-56.

13. Mo J, Tang C, Li J, Guan L, Huang Z. Experimental investigation on the effect of n-butanol blending on spray characteristics of soybean biodiesel in a common-rail fuel injection system. Fuel 2016; 182:391-401.

14. Kegl B. Influence of biodiesel on engine combustion and emission characteristics. Applied Energy 2011;88: $03-$ 12.

15. Zareh P, Zare A, Ghobadian B. Comparative assessment of performance and emission characteristics of castor, coconut and waste cooking based biodiesel as fuel in a diesel engine. Energy 2017; 139: 883-894.

16. Perdomo-Hurtado L, Tabares J, Correa D, Perdomo F. Castor oil preheater selection based on entropy generation and exergy effectiveness criteria. Energy 2017; 120: 805-815.

17. Pugazhvadivu M, Sankaranarayanan G. Experimental studies on a diesel engine using mahua oil as fuel. Indian Journal of Science and Technology 2010; 3: 787-791.

18. Du E, Cai L, Huang K, Tang H, Xu X, Tao R. Reducing viscosity to promote biodiesel for energy security and improve combustion efficiency. Fuel 2018; 211: 194196.

19. Tesfa B, Mishra R, Gu F, Powles N. Prediction models for density and viscosity of biodiesel and their effects on fuel supply system in CI engines. Renewable Energy 2010; 35: 52-60.

20. Gülüm M, Bilgin A. Measurements and empirical correlations in predicting biodiesel-diesel blends' viscosity and density. Fuel 2017; 199: 567-577

21. Fahd MEA, Lee PS, Chou SK, Wenming Y, Yap C. Experimental study and empirical correlation development of fuel properties of waste cooking palm biodiesel and its diesel blends at elevated temperatures. Renewable Energy 2014; 68:282-8.

22. Murillo S, Míguez J, Porteiro J, Granada E, Morán J. Performance and exhaust emissions in the use of biodiesel in outboard diesel engines. Fuel 2007; 86:17651771.

23. Kumar J, P. Reddy M, K. Reddy H. Effect of Fuel Temperature on Diesel Engine Performance and Emissions using Cotton Seed Based Bio-Diesel and Additive Ac2010a. International Journal of Green Chemistry and Bioprocess 2014; 4: 9-13.

24. Roy M, Wang W, Bujold J. Biodiesel production and comparison of emissions of a DI diesel engine fueled by biodiesel-diesel and canola oil-diesel blends at high idling operations. Applied Energy, 2013; 106: 198-208.

25. Bari, S., Lim, T., Yu, C. Effects of preheating of crude palm oil (CPO) on injection system, performance and emission of a diesel engine. Renewable Energy 2002:27; 339-351.

26. Hazar, H., Aydin, H. Performance and emission evaluation of a CI engine fueled with preheated raw rapeseed oil (RR0)-diesel blends. Applied Energy 2010: 87: 786-790.
27. Pugazhvadivu M, Sankaranarayanan G. Experimental studies on a diesel engine using mahua oil as fuel. Indian Journal of Science and Technology 2010; 3: 787-791.

28. Du E, Cai L, Huang K, Tang H, Xu X, Tao R. Reducing viscosity to promote biodiesel for energy security and improve combustion efficiency. Fuel 2018; 211: 194196.

29. Tesfa B, Mishra R, Gu F, Powles N. Prediction models for density and viscosity of biodiesel and their effects on fuel supply system in CI engines. Renewable Energy 2010; 35: 52-60.

30. Ruhul A, Kalam M, Masjuki H, Shahir S, Alabdulkarem A, Teoh Y, How H, Reham S. Evaluating combustion, performance and emission characteristics of Millettia pinnata and Croton megalocarpus biodiesel blends in a diesel engine. Energy 2017; 141: 2362-2376.

31. Murillo S, Míguez J, Porteiro J, Granada E, Morán J. Performance and exhaust emissions in the use of biodiesel in outboard diesel engines. Fuel 2007; 86:17651771.

32. Kumar J, P. Reddy M, K. Reddy H. Effect of Fuel Temperature on Diesel Engine Performance and Emissions using Cotton Seed Based Bio-Diesel and Additive Ac2010a. International Journal of Green Chemistry and Bioprocess 2014; 4: 9-13.

33. Stojkovic IJ, Miladinovic MR, Stamenkovic OS, Bankovic IB, Povrenovic DS, Veljkovic VB. Biodiesel production by methanolysis of waste lard from piglet roasting over quicklime. Fuel 2016; 182:54-66.

34. Bueno A, Pereira M, Pontes J, Luna F, Jr C. Performance and emissions characteristics of castor oil biodiesel fuel Blends. Applied Thermal Engineering 2017; 125: 559566 .

35. Fadhil A, Al-Tikrity E, Albadree M. Biodiesel production from mixed non-edible oils, castor seed oil and waste fish oil. Fuel 2017; 210: 721-728.

36. Roy M, Wang W, Bujold J. Biodiesel production and comparison of emissions of a DI diesel engine fuelled by biodiesel-diesel and canola oil-diesel blends at high idling operations. Applied Energy 2013;106:198-208.

37. An H, Yang WM, Maghbouli A, Chou SK, Chua KJ. Detailed physical properties prediction of pure methyl esters for biodiesel combustion modeling. Applied Energy 2013; 102: 647-656

38. Muralidharan K, Vasudevan D. Performance, emission and combustion characteristics of a variable compression ratio engine using methyl esters of waste cooking oil and diesel blends. Applied Energy 2011;88: 59-68.

39. Elsanusi O, Roy M, Sidhu M. Experimental Investigation on a Diesel Engine Fueled by Diesel-Biodiesel Blends and their Emulsions at Various Engine Operating Conditions. Applied Energy 2017; 203: 582-593

40. Mourad M, Mohamed F, Mahmoud K, Nouh A. Influence of Biodiesel Fuel on Performance Characteristics of Hybrid Electric Vehicle According to Urban Driving Cycle. The International Renewable Energy Congress IREC, Tunisia. 2014; March 25-27

41. Roy M, Calder J, Wang W, Mangad A, Diniz F. Cold start idle emissions from a modern Tier-4 turbo-charged diesel engine fueled with diesel-biodiesel,dieselbiodiesel-ethanol, and diesel-biodiesel-diethyl ether blends. Applied Energy 2016; 180:52-65.

42. Baskar P, Senthilkumar A. Effects of oxygen enriched combustion on pollution and performance characteristics of a diesel engine. Engineering Science Technology international Journal 2016; 19: 38-43.

43. Li B, Li Y, Liu H, Liu F, Wang Z, Wang J. Combustion and emission characteristics of diesel engine fueled with biodiesel/PODE blends. Applied Energy 2017; 206: 425-431. 
44. He B-Q. Advances in emission characteristics of diesel engines using different biodiesel fuels, Renewable and Sustainable Energy Reviews 2016; 60: 570-586.

45. Roy M, Calder J, Wang W, Mangad A, Diniz F. Emission analysis of a modern Tier 4 DI diesel engine fueled by biodiesel-diesel blends with a cold flow improver (Wintron Synergy) at multiple idling conditions. Applied Energy 2016; 179:45-54.

46. Hasan M, Rahman M. Performance and emission characteristics of biodiesel-diesel blend and environmental and economic impacts of biodiesel production: A review. Renewable and Sustainable Energy Reviews 2017; 74: 938-948.

47. Yu S, Yin B, Jia H, Wen S, Li X, Yu J. Theoretical and experimental comparison of internal flow and spray characteristics between diesel and biodiesel. Fuel 2017; 208: 20-29.

48. Özener O, Yüksek L, Ergenç AT, Özkan M. Effects of soybean biodiesel on a DI diesel engine performance, emission and combustion characteristics. Fuel 2014; 115 : $75-83$.

\section{Biographical notes}

Biographical notes is not available. 
